\title{
Degrees of Proximity in the Age of HIV
}

\section{DAVID HERKT}

\author{
David Caron \\ The Nearness of Others: Searching for Tact and Contact in the Age of HIV \\ University of Minnesota Press, Minneapolis, 2014 \\ ISBN 9780816691791 RRP US\$24.95
}

HIV/AIDS has become the forgotten virus. From the singular and spectacular position it once held, it has largely disappeared from public awareness, superseded by newer and somehow more urgent viral threats, like Ebola. The writing of HIV/AIDS in the Western world has proven to be a near-finite phenomenon, at its peak in the period of time between 1982 and 1996, when the efficacy of new treatments was announced by the Centers for Disease Control and Prevention (CDC) in the United States of America. In slightly under fifteen years, a disease and its human ramifications had been defined, explosively chronicled, and then consigned to a comparative silence.

This discursive flowering and fading is rare in such compressed form.

The early moments of description, when the nature of a disease is delimited, have still not been thoroughly explored epistemologically. We still lack any real archaeology of those decisions by which diseases are isolated symptomatically from ISSN 1837-8692

Cultural Studies Review 2015. @ 2015 David Herkt. This is an Open Access article distributed under the terms of the Creative Commons Attribution 4.0 Unported (CC BY 4.0) License (https://creativecommons.org/licenses/by/4.0/), allowing third parties to copy and redistribute the material in any medium or format and to remix, transform, and build upon the material for any purpose, even commercially, provided the original work is properly cited and states its license. 
surrounding phenomena in the process of knowledge production. HIV was also different from other recent diseases in that its major effect was to compromise the immune system; death came as a consequence of other opportunistic infections. It was therefore difficult to conceptualise.

Then there were the human consequences upon individuals, groups, organisations and societies, who produced records of their developing encounters with the virus in a vast range of media, including medical files, news reports, public health messages, documentary and art works. During the late 1980s and early 1990s, there was also a particular elegiac memorialising urgency in the face of an expanding epidemic and increasing deathrates. The need to witness and to testify became paramount. There is a whole literature of HIV written on the edge of the grave.

However, post-1996, concurrent with the efficacy of new treatments and the decline of AIDS-related mortality, these social and cultural consequences lessened. HIV/AIDS gradually became a setting, not an emphasis. It retreated into the omnipresent background static of an acceptable medical circumstance. HIV/AIDS, it seems, had become no more publicly concerning than any other communicable disease.

Given this progression, whether David Caron's 2014 book The Nearness of Others: Searching for Tact and Contact in the Age of HIV could be described as a manifestation of Late HIV/AIDS is something that it will become necessary to address. The Nearness of Others is an attempt to examine, for the early twenty-first century, the liminal spaces that exist between individuals with HIV and their social environment. The book delineates a relationship with the virus that would have been unimaginable twenty years before its publication. Caron's description is also personal. He is HIV positive, a professor of English and French studies at the University of Michigan, the author of AIDS in French Culture: Social Ills, Literary Cures. His is a view from the inside.

The Nearness of Others is a series of tacks or slants from, around and towards the subject. Sometimes intimate, sometimes more general, the book's fragmentary sections range between a paragraph and several pages, arranged into broader categories ('Diagnosis', 'Others', 'Disclosure', 'Taste', 'Tact', 'Contact' and 'Names'). While their compound effect explores the events, echoes and epistemic 
consequences of being HIV positive, the book is also an examination of the possibility of an ethics of HIV/AIDS. How does an HIV positive man exist ethically? What boundaries permit and constrain? How do considerations about behaviour occur under these circumstances? What factors are reflected in the decisions that are made?

It is a narrative of degrees of proximity. Caron chronicles the distances of the age, from the complicities of infection to the exigencies of discussion. 'One isn't HIV positive in a vacuum but in the world, near the bodies, actions, and feelings of people with whom we share this world', he writes. 'Living with HIV means living alongside people without HIV in a world where the virus is saturated with meaning.' (319) As opposed to the life and death matters of early HIV/AIDS, Caron's work often focuses on an etiquette of HIV, a decorum which can feel disturbing after the urgency of the texts from the first 'plague years'. The Nearness of Others is, in effect, a philosophic book of attitudes and manners late in an epidemic. Caron explores acts of disclosure and concealment. His autobiographical account extends our knowledge of how the person of the infected body negotiates relationships both with themselves and with others, and, in a broader sense, with their society and culture. 'There is no other experience of HIV than one saturated with politics and culture', (24) Caron reiterates, and takes his discussion from the personal to the cultural. HIV draws a line between those with the virus and those without, complicated by the act of observation.

These lines of demarcation, in a social sense, inevitably involve reflection back upon the self: 'disclosure, far from being a kind of externalization, allowing the excluded to reintegrate into the group, is in fact the very process by which exclusion becomes internalized and accepted as an inherent quality of the person, not as the effect of the cultural forces it really is'. (174) Caron examines the life of an HIV positive man, from the communication of the medical fact of seropositivity to the shared complicity of HIV status. These examples, due to Caron's background, are usefully trans-Atlantic, and the straddling of cultures has the consequence of widening Caron's purview. He has the ability to compare French and American responses to great effect. He links the racial politics of France, particularly the debate about the public wearing of the hijab, with HIV status and its signifiers in the United States. It is an illuminating example. 
Caron's use of the internet in his sexual life also adds a world of technological mediation and its strategies to the discussion. The interval of the internet, creating both distance and proximity, is one of the prominent features of recent time, and its ramifications extend into the world of HIV. Caron outlines the shifting and porous boundaries of the ethics of online 'poz' contact, and its social, sexual and emotional consequences.

Caron's range of cultural reference extends from traditionally 'camp' movies like $A$ Star is Born and gay icons like the singer Rufus Wainwright, to death-camps in Cambodia and Auschwitz. It includes 9/11's Ground Zero and the behaviours of homosexual cruising. The balance can sometimes appear both disturbing and overwrought, but this disparate range is not without effect; 'Depression kicked in', Caron writes, 'when it occurred to me that not only was I HIV positive, but I still had to do the laundry.' (17)

In The Nearness of Others, HIV is situated in a world of media and instantaneous social communication, where the weighting of factors does not conform to any traditional scale of high and low, where impact is gauged by individual response in a raft of perceptions. A reader is also placed variously by the text, admitted and made complicit, or held at arm's length. While at times Caron can reach towards the explicit moments of shared narrative and cultural intimacy, at other times he omits facts entirely. Primarily, this centres on the act of Caron's infection. Caron withholds this moment, whereas in the past this instant of infection was defining: personally, socially and politically.

The diagnosis of Caron's seropositivity occurred, as he describes in the book's first section, in 2006. However, unlike the first-person works by other writers of the early years of HIV/AIDS, such as those by Paul Monette, David Wojnarowicz, Harold Brodkey and Hervé Guibert, Caron's recounting is vastly more distanced. ${ }^{1}$ Where these earlier writers often focused on the circumstances of infection as crucial moments in a definition of being, Caron refuses this reading. He deals, instead, with the aftermath. This historic difference cannot be overstated.

The key word in Caron's book is 'tact'; The Nearness of Others is a tactful text. It foregrounds the choice of a narrator to tell or not to tell his or her story, in his or her way. 'Affect isn't located in words but in gaps, and this is especially true of grief and sorrow.' (70) Tact, however, is not a closure of exterior inquiry, but an alteration of 
it. "To turn away and ejaculate safely registers here as a sign of care for the other but also as a reminder of times when contacts were more direct, more involved perhaps. As for the silence that extends from the encounter in the park to the rest of the city, it doesn't deny reality but, on the contrary, acknowledges with tact the ravages of the epidemic.' (284)

Acknowledgement, however, is a broader issue than tact. 'Disclosure is thus not the end of enclosure but the beginning of a spiral of policing and control,' Caron writes of the act of communicating HIV-status. (181) This control is central in a number of countries and states where legal powers compel notification of serostatus to government agencies, as well as in every aspect of personal relations. Caron coins a neologism, 'dysclosure', to expose 'the inherent dysfunction of confessional disclosure' (181). Dysclosure is situational. It is relational. It is unending. It is the heart of Caron's text, responsible for its form and its content. 'Who I am with HIV is thus in constant flux, shifting as the meanings of HIV that continue to circulate in the world without my direct involvement in them intersect with those I make every time I disclose and put my body on the line.' (186) Truth, for Caron, is bricolage: in relation, positioned and positioning, always changing.

Caron constructs a mosaic of consideration and reaction in The Nearness of Others but its tesserae frequently scatter any argument. He delimits a field. It is a boundary of engagement, recorded at a moment when contemporary HIV/AIDS is not being considered or documented with any great degree of thoroughness. It is, as a consequence, without resolution. Caron's first-person experience is evidence, just as it is commentary from someone involved. There are reflections on shared towels and gestures, on living together and negotiating trust, on the acts of writing and reading an epidemic, and the act of refusing to do so. The Nearness of Others never reaches towards an overarching thesis or summa. There will, however, be a future in which Caron's text will figure as part of how we reacted to HIV/AIDS in the early twenty-first century, as a glimpse of human comprehension and human action, and the possibilities and limits of an individual's empowerment and control. 
David Herkt is a former HIV/AIDS educator. He has written, researched and directed the three-part documentary series High Times: A Cultural History of Drug-Use in New Zealand which gained a New Zealand Film and Television Award for 'Best Factual Series'. He lives in Auckland, New Zealand.

\section{-NOTES}

1 Paul Monette's Borrowed Time: An AIDS Memoir, Harcourt Brace Jovanovich, New York, 1988, David Wojnarowicz's Close to the Knives: A Memoir of Disintegration, Vintage Books, New York, 1991, Harold Brodkey's This Wild Darkness, Henry Holt, New York, 1996 and Hervé Guibert, À l'ami qui ne m'a pas sauvé la vie (translated and published in English as To the Friend Who Did Not Save My Life, High Risk/Serpent's Tail, New York and London, 1996) are now canonical examples of early personal experiences of HIV/AIDS, where the political and the personal are interwoven with urgency to stimulate action.

\section{-BIBLIOGRAPHY}

Brodkey, H., This Wild Darkness, Henry Holt, New York, 1996.

Guibert, H., To the Friend Who Did Not Save My Life, High Risk/Serpent's Tail, New York and London, 1996.

Monette, P., Borrowed Time: An AIDS Memoir, Harcourt Brace Jovanovich, New York, 1988.

Wojnarowicz, D., Close to the Knives: A Memoir of Disintegration, Vintage Books, New York, 1991. 